\title{
Academic Staff Training and the Challenges of Accessing TETFund in Southwest Nigerian Universities
}

\author{
Comfort O. Akomolafe, Fawziyah A. Belo \\ Department of Educational Management, Ekiti State University \\ Ado-Ekiti, Nigeria
}

\begin{abstract}
This study examined academic staff training and the challenges of accessing TETFund in Southwest Nigerian Universities. The study population comprised all the lecturers in Southwest Nigerian Universities from which a sample of 500 academic staff members was drawn from 5 Universities using simple random and stratified sampling techniques. A self-designed instrument tagged "Academic Staff Training and the Challenges of Accessing TETFund Questionnaire." (ASTCATQ) was used to gather information from the respondents. The instrument was validated with a reliability coefficient of 0.75 . The research question was answered with mean and standard deviation while the hypotheses were tested with ANOVA at 0.05 level of significance. The study revealed that there were many challenges inherent in accessing TETFund by members of the academic staff. A significant difference in the academic staff perception of the challenges of accessing TETFund for their training on the basis of their status was reported in the study. The study however revealed that there was no significant difference in the perception of the challenges involved in accessing TETFund for academic staff training based on their administrative experience. It was concluded on the basis of the findings of the study that the challenges inherent in accessing TETFund play a major role in hindering academic staff training in Southwest Nigerian Universities. It was therefore recommended that government and University management should endeavour to reduce the various challenges involved in accessing TETFund for academic staff training to the barest minimum.
\end{abstract}

\section{Introduction}

The importance of education in the overall development of an individual cannot be over emphasized. This is because education serves as an avenue for removing individuals from the shackles of ignorance, unemployment and poverty and also the bedrock for every development that occurs in the society. This perhaps might be the reason why the [1] averred in the National Policy on education that education is the greatest investment that the nation can offer for the quick development of her economic, political, sociological and human resources. In a related development, [2] contended that education as an essential virtue and necessity of the society is a process of acquiring knowledge, skills and values needed to aid personal and professional growth of individuals.

The contribution of university education to the socio-political, economic and technological advancement of a nation cannot be over emphasized. This is because it is the peak in the three levels of education and also one of the various tertiary educational institutions through which the nation hopes to achieve its visions. Its roles include teaching, research and community services. In order to effectively perform these roles, it thus become imperative that its academic staff be engaged in continuous training and researches so as to facilitate the production of manpower (students) that would effectively key into the professions of their choice. [3] however noted that the Nigerian government over the years have not been meeting the United Nation Educational Scientific and Cultural Organization (UNESCO) recommendation of $26 \%$ of the local budget allocation to education sector.

Similarly, [4] noted a general decay in human and material resources in Nigerian tertiary institutions due to poor funding which according to them have contributed to poor teacher quality, poor academic performance of students, low rating of institutions, recruitment of unqualified teachers among others. [5] equally affirmed that university education in the contemporary Nigeria has focused itself at the crossroads of continuous lack of funding from the traditional sources despite the fact that it is explicitly clear that education is one of the most viable and biggest industry in almost every modern economy. Mgbekem summed it up in [5] that the major challenge facing the management of University system in Nigeria is inadequate funding.

It is not uncommon to see some academic staff being on a level for a long period of time in Nigerian Universities. The reason for this could be traced to the popular saying in the academic kingdom that it is either one publishes or perishes. Stagnation of academic staff on a level could be due to the challenges involved in accessing the available fund that could enhance their participation in trainings and other programmes that would keep them updated on 
the job. If this lingers on, students who are the products of academic staff will also be affected because of the usual saying that one can only give what he or she has and since the lecturers do not update their knowledge, ideas and skills via training and re training, they therefore continually teach the student with the conservative teaching methods which could hinder delivery of quality education.

A peep into the country's University system shows that over the years, university education have been bedevilled with different problems ranging from financial, human to insufficient material resources. The degeneration of University education led to the federal government embarking on various measures of repositioning the University system. Corroborating this, [6] in his words affirmed that the lecturers are their priority in TETFund's intervention policy because they are the drivers of communication and knowledge. He added that if you take away the lecturers, you have created a gap that you cannot fill in educational development. He thus concluded that the Federal Government of Nigeria therefore set up Tertiary Education Trust Fund in 2011 to serve as a relief in funding academic staff training among other objectives in tertiary institutions so as to alleviate the problem of stagnation. Going by Bogoro's assertion, it could be said that the primary aim of establishing TETFund was the training of academic staff in order to boost their personal and professional development which could in turn enhance their productivity in the University system.

[7] reported that TETFund was originally established as Education Tax Fund (ETF) by the Education Tax Act No. 7 of 1993 and amended by Act No. 40 of 1998. They explained that the fund had a mandate to operate as an intervention fund to all levels of public education and that the pressures on ETF made it practically impossible for her to meet up with University needs. Hence, it was thereafter repealed and replaced with Tertiary Education Trust Fund Act 2011 that was charged with the responsibility of providing supplementary support to all public tertiary institutions with the main objective of rehabilitating, restoring and consolidating tertiary education in Nigeria.

[8] explained that TETFund was established as a result of the deteriorating infrastructure in the country's education sector which according to him was evidenced by poor training, poor staff quality and poor resources, rapid personnel turnover, unrest in the form of student riots and Universities staff strike action combined with falling standards of education, the increase in illiteracy and low-level numeracy which paved the way for negotiations on educational crises in Nigeria in the 1980s. He explained that TETFund was established based on the outcome of a series of negotiation between the federal government of Nigeria, representatives of the Academic Staff Union of Universities and the private sector. He concluded that the Academic Staff Union of Universities of Nigeria had an agreement with the federal government, part of which led to the introduction of a $2 \%$ education tax on assessable corporate profit. It could be inferred from Bogoro's assertion that irregular staff training and degeneration of University education is not a new phenomenon in the academic parlance. In realisation of the importance of academic staff training in tertiary institutions, the federal government of Nigeria therefore established TETFund to act as a succour to the academic staff.

[9] empowers the Federal Inland Revenue Service (FIRS) to collect $2 \%$ as education tax on the assessable profit of all registered companies in Nigeria. The act was empowered with the management, disbursement and monitoring of education tax to Nigerian public tertiary institutions with the intent of improving the quality of higher education which could be obtained through improved staff productivity. The mandate of TETFund as provided in section 7(1) (a) to (e) is to administer and disburse fund to Federal and State public tertiary institutions specifically for the provision and maintenance of the following;

1. essential physical infrastructure for teaching and learning;

2. instructional materiasl and equipment;

3. research and Publication;

4. academic staff training and development; and,

5. any other need which in the opinion of the board of trustees is critical and essential for the improvement of quality and maintenance of standard in higher educational institutions [9]

It could be inferred from the above that the main focus of TETFund was to generate additional income to support tertiary education in a bid to strengthen staff productivity which would in turn improve the quality of higher education. However, some challenges are inherent in the assessment of the fund by academic staff in Southwest Nigerian Universities. Some of the observed challenges include delay in the approval of fund, stringent conditions attached to fund accessment, approval of insufficient fund for the expected programme, administrative bottlenecks among others. It is worthy of note that these and other challenges of accessing TETFund by academic staff differs on the basis of their experience and status.

It is an axiom that knowledge is dynamic and not static. Thus, the knowledge acquired today can become obsolete tomorrow if not updated. Corroborating this, [10] noted that development helps to recharge teachers' intellectual battery with new electrolytes of knowledge and ideas. By implication, this means that academic staff in Universities need to be given the opportunity to develop on the job in order to acquire new knowledge, skills and abilities in order 
to grow and contribute maximally to the attainment of University's goals. There is no doubt that academic staff play a significant role in ensuring excellent academic standards measured by students' learning outcomes in both developed and developing countries. Hence, their importance in the Universities cannot be underestimated because continuous staff training is the hallmark of effectiveness at work.

Training which can be described as a planned specialised process undergone by employees to acquire when, why and how to obtain new skills, techniques and attitude that could enhance their positive contribution to the organisation is an effective tool for organisational success. By implication, any organisation that aimed at achieving its stated goals must be ready to develop her human resources because the success of any organisation to a very large extent depends on the effectiveness of their human resources since they are the one manipulating the material resources. To prevent academic staff from being obsolete and rustic, it therefore becomes essential that they regularly update themselves on the new skills, knowledge and pedagogy which can mostly be done through training and re-training which could be in from of seminars, workshops or conferences.

[11] sees training as a planned organisational effort concerned with helping an employee to acquire specific and immediately usable skills, knowledge, concepts attitudes and behaviours to enable him or her perform more efficiently and effectively on his or her present job. [12] defined training as the teaching of vocation or practice that relate to specific skills. He explained that training is a process of increasing human efficiency through which people are offered the opportunity to acquire new skills and current knowledge required in carrying out various specialised tasks in their place of work. Ebong and Ezekiel in [13] submitted that training is crucial as one of the staff development procedure. They explained that an employee may have the qualification needed for a job but may not have the necessary experience and skills to perform the required task effectively. It could be inferred from the above submissions that the effectiveness of an academic staff in the University hinges on the series of training acquired on the job. It thus becomes imperative for academic staff members to be regularly trained on the job in order to empower them with the required skills, techniques of coping with the changing society.

Staff training are the programmes undertaken by employees in order to facilitate their professional and personal advancement. It is essential that for the goals and objectives of organizations to be achieved, the organizational staff need to partake in various programmes that would strengthen their productivity. [14] affirmed that development is not a stage to be attained or a goal to aim at but rather a constant process of improvement in which education and research, workshops and conferences play prominent roles in creating positive change in the self, people around us, our communities as well as the institutions and structures that surround us. Buttressing this, [6] stated that foreign training is a necessary element for the creation of a pool of personnel required for sustenance of research and development activities in the third world and will remain so for the foreseeable future. He added that these advanced countries have the infrastructure, the human resources and capacity to train personnel to the higher international levels. It could be inferred from the above that academic staff knowledge needs to be updated on a regular basis so as not to become obsolete, and this could mostly be achieved through regular and effective training which would in turn enable them make meaningful contributions to the achievement of University's goals.

A scenario in Nigerian Universities however indicates a decline among the academia due to lack of fund for research and publication. It is a known fact that an academic staff that does not update himself/herself in his/her area of study cannot maximally contribute to educational development and one of the cogent reasons inhibiting update of lecturers' knowledge could be the challenges involved in accessing fund through TETFund. [7] noted that in spite of the intervention of TETFund in the area of staff training, many tertiary institutions are unable to meet the conditions for accessing funds allocated to them. They concluded that many academic staff thus miss the opportunities to access the free funds for academic training and development. [15] equally remarked that many institutions complained that the process of accessing the fund is cumbersome. He explained that TETFund alone cannot take all the blames, but the managers of the institutions are also to be blamed for not publicising the fund. Another hindrance of accessing the fund according to him is the in-house politics at the institution level. He therefore suggested that academic staff and institutions' management should work towards achieving timely and successful completion of proposals in order to access the fund earmarked for them. The reason why academic staff miss the golden opportunity of getting fund through TETFund intervention could be traced to the series of challenges inherent in accessing the fund.

Administrative experience connotes different positions being held by academic staff. These positions range from Head of Department, Director of Programmes, Dean, Deputy Vice Chancellor to Vice Chancellor. It is believed that academic staff administrative experience could positively affect their perception of the challenges inherent in accessing TETFund. This is because over the years, they have assumed different positions which could eventually elude them from encountering the challenges inherent in obtaining fund for their training through TETFund. 
However, there is the likelihood that lecturers who do not have enough administrative experience are prone to the various challenges of accessing fund through TETFund than their counterparts that have held series of positions over a long period of time. If care is not taken, the latter may experience delay in research, publication and training which would aid their advancement on the job.

In every organizations, workers are classified into two categories vis a vis senior and junior cadre. In the University system, those at the senior cadre comprised professors, associate professors and senior lecturers while the junior cadre consists of lecturer 1 and below. It is assumed that those in the senior cadre would face lesser challenges in accessing fund through TETFund probably because of their status or experience than their counterparts in the junior cadre. However, academic staff in the junior cadre could undergo training through TETFund without encountering challenge in accessing the fund.

TETFund which serves as a succour to the academia plays a major role in their advancement on the job. Existing evidence revealed linkages between TETFund intervention and its impact on academic staff training. [16] explained that the future of an organization does not only depend on providing a product that is competitive in price, quality, quantity and increment in range of products produced but rather, the organization's ability in sustaining visionary workers full of improved skills, knowledge, energy and experience to direct the force and facilities needed in achieving the organizational goals.

Similarly, Arikewuyo and Adegbesan in [6] contended that the importance of sustaining national and international quality cannot be over emphasized. They explained that education for life entail updating the knowledge of the academic staff, improving their teaching skills as well as establishing appropriate academic staff development structure. It could be inferred from these submissions that the achievement of the objectives of University education can mainly be guaranteed if her human resources are regularly developed. It therefore becomes imperative that the development of lecturers' knowledge and skills be supported in Nigerian Universities in order to enhance realization of lecturers' potentials for self-growth and University's development and it is believed that this could mostly be achieved in this era of economic recession (when most universities cannot afford to sponsor their academic staff for training and conferences due to paucity of fund) through TETFund. It is against this background that this study investigated academic staff training and challenges of accessing fund through TETFund in southwest Nigerian Universities.

\section{Statement of the Problem}

One of the objectives of TETFund is the provision and maintenance of academic staff training and development in order to enhance the accomplishment of University goals. Observation has shown that some academic staff are not productive due to their inadequate participation in trainings where they could acquaint themselves with modern pedagogies and skills that could enhance their personal and professional development. This problem has been of concern to stakeholders in the University system because often times, most of her academic staff cannot afford self-sponsorship and the challenges inherent in accessing TETFund usually discourage the academic staff from applying for the fund for training. This study thus investigated academic staff training and the challenges of accessing fund through TETFund intervention in southwest Nigerian Universities. The aim is to provide answers to the challenges of accessing TETFund, and also take into consideration the challenges inherent in accessing the fund based on the administrative experience and status of academic staff. In addressing this problem, a research question was raised thus;

1. What are the challenges of accessing fund for training through TETFund?

\section{Hypotheses}

To guide this study, the following hypotheses were generated;

1. There is no significant difference in the perception of challenges of accessing TETFund for training based on staff administrative experience.

2. There is no significant difference in the perception of challenges of accessing fund for training through TETFund based on the status of academic staff.

\section{Methodology}

The descriptive research design of the survey type was used for the study. All the academic staff in southwest Nigerian Universities made up the population for the study while a sample of 500 academic staff was selected from 5 Universities using simple random and stratified sampling techniques. To achieve this, 5 states were randomly selected from the 6 states in southwest which was followed by random selection of one university in each state making a total of 5 universities. 500 academic staff were thereafter selected using stratified sampling technique at the rate of 100 academic staff per university. A self-designed instrument tagged "Academic Staff Training and the Challenges of Accessing TETFund Questionnaire" (ASTCATQ) was administered on the selected 
academic staff. The face and content validity were established by experts in the departments of Educational Management and Tests and Measurement in the Faculty of Education, Ekiti State University. The reliability of the instrument was established through test-retest method. This was done by administering the instrument twice within an interval of two weeks on 30 academic staff in a university and they were not part of the sample used for the study. The two sets of responses were correlated using Pearson's Product Moment Correlation and a reliability coefficient of 0.75 was obtained. The research question was answered with mean and standard deviation while the hypotheses were tested with ANOVA. The hypotheses were tested at 0.05 level of significance.

\section{Data Analysis and Results}

Research Question 1. What are the challenges of accessing fund for training through TETFund? Challenges of Accessing TETFund

\begin{tabular}{|c|c|c|c|c|c|}
\hline Items & & S.D & $\begin{array}{l}\text { Expecte } \\
\text { d Mean }\end{array}$ & $\begin{array}{l}\text { Actua } \\
1 \\
\text { Mean } \\
\end{array}$ & Remark \\
\hline 1. & $\begin{array}{l}\text { Access to } \\
\text { fund is } \\
\text { cumberso } \\
\text { me }\end{array}$ & $\begin{array}{l}0.7 \\
8\end{array}$ & 2.5 & 3.31 & High \\
\hline 2. & $\begin{array}{l}\text { Delay in } \\
\text { the } \\
\text { approval } \\
\text { of fund }\end{array}$ & $\begin{array}{l}0.9 \\
0\end{array}$ & 2.5 & 3.28 & High \\
\hline 3. & $\begin{array}{l}\text { Fund } \\
\text { approved } \\
\text { for the } \\
\text { expected } \\
\text { programm } \\
\text { e is } \\
\text { inadequate }\end{array}$ & $\begin{array}{l}0.9 \\
7\end{array}$ & 2.5 & 3.05 & High \\
\hline 4. & $\begin{array}{l}\text { Pride of } \\
\text { staff in } \\
\text { processing } \\
\text { the fund }\end{array}$ & $\begin{array}{l}1.1 \\
2\end{array}$ & 2.5 & 2.88 & High \\
\hline 5. & $\begin{array}{l}\text { Some staff } \\
\text { have low } \\
\text { level of } \\
\text { awareness } \\
\text { about the } \\
\text { fund }\end{array}$ & $\begin{array}{l}0.9 \\
2\end{array}$ & 2.5 & 2.55 & $\begin{array}{l}\text { Moderat } \\
\mathrm{e}\end{array}$ \\
\hline 6. & $\begin{array}{l}\text { Stringent } \\
\text { conditions } \\
\text { hinder } \\
\text { easy } \\
\text { access }\end{array}$ & $\begin{array}{l}0.9 \\
2\end{array}$ & 2.5 & 2.55 & $\begin{array}{l}\text { Moderat } \\
\mathrm{e}\end{array}$ \\
\hline 7. & $\begin{array}{l}\text { Some } \\
\text { regulation } \\
\mathrm{s} \\
\text { discourage } \\
\text { programm } \\
\text { e } \\
\text { attendance }\end{array}$ & $\begin{array}{l}0.9 \\
0\end{array}$ & 2.5 & 3.13 & High \\
\hline 8. & $\begin{array}{l}\text { Low level } \\
\text { of staff } \\
\text { awareness } \\
\text { in the } \\
\text { procedure }\end{array}$ & $\begin{array}{l}0.8 \\
0\end{array}$ & 2.5 & 2.75 & High \\
\hline
\end{tabular}

for processing the fund

Table 1 shows that the expected mean of all the items was 2.5. Hence, items whose actual means were above the expected mean have higher responses while those within the limit of the expected mean were moderate.

Hypothesis 1: There is no significant difference in the perception of the challenges of accessing TETFund for training by academic staff based on their administrative experience.

Table 2. One-way ANOVA of the perception of the challenges of accessing TETFund for training based on academic staff administrative experience

\begin{tabular}{llllll}
\hline Source & SS & Df & Ms & Fcal & Ftab \\
\hline Between & 144.716 & 3 & 48.239 & & \\
Groups & & & & 2.053 & 2.60 \\
Within & 11651.946 & 496 & 23.492 & & \\
Groups & & & & & \\
Total & 11796.662 & 499 & & & \\
\hline $\mathrm{p}>0.05$ & & & &
\end{tabular}

Table 2 shows that F-calculated (2.053) was lesser than F-table (2.60) at 0.05 level of significance. The null hypothesis was therefore accepted. This implies that there was no significant difference in the perception of the challenges of accessing TETFund for academic staff training based on their administrative experience.

Hypothesis 2: There is no significant difference in academic staff perception of the challenges of accessing TETFund for training based on their status.

Table 3. One-way ANOVA of the status of academic staff and their perception of the challenges of accessing TETFund for training.

\begin{tabular}{llllll}
\hline Source & SS & Df & M & Fcal & Ftab \\
\hline Between & 362.282 & 3 & 120.761 & & \\
Groups & & & & & 2.60 \\
Within & 9503.750 & 496 & 19.161 & 6.302 & \\
Groups & & & & & \\
Total & 9866.032 & 499 & & & \\
\hline $\mathrm{P}<0.05$ & & & &
\end{tabular}

Table 3 reveals that F-calculated (6.302) was greater than F-table (2.60) at 0.05 level of significance. The null hypothesis was therefore rejected. This implies that there was significant difference in the perception of the challenges of accessing TETFund for academic staff training based on their status. 


\section{Discussion}

The study revealed that there are many challenges inherent in accessing TETFund for training by academic staff; some of which include cumbersome procedure for accessing the fund, low level of staff awareness about the fund, stringent conditions among others. The implication of this is that the challenges involved in accessing fund for academic staff training is on a high level. Probable reason for this could be because the available fund could not go around the academic staff when the need for it arises. Hence, the introduction of some policies which could be interpreted by some academic staff as challenges. Another probable reason could be to checkmate abuse of the fund. This finding is in line with [7] who reported that some challenges such as lecturer's inability to meet up with the conditions of the fund, stringent conditions among others are inherent in accessing TETFund.

The study revealed that there was no significant difference in the perception of the challenges involved in accessing TETFund for academic staff training on the basis of their administrative experience. This implies that academic staff administrative experience do not have any influence on their perception of the challenges involved in accessing TETFund. That is, an academic staff that is serving either as an HOD or Director, Dean among others perceived the challenges inherent in accessing TETFund same way other lecturers without administrative experience perceived it. Reason for this might probably be due to the fact that there is no column for stating one's administrative experience when processing the fund.

A significant difference in the academic perception of the challenges in accessing TETFund for their training based on their status was also reported in the study. By implication, perception of the challenges of accessing TETFund by academic staff in the senior cadre was lesser than the perception of those in the junior cadre. This might not be unconnected with the general belief that academic staff in the senior cadre should have a better knowledge of overcoming the challenges than their counterparts that are green on the job.

\section{Conclusion}

Based on the findings of this study, it was concluded that the challenges inherent in accessing TETFund plays a major role in hindering academic staff training in South West Nigerian Universities. The following recommendations were made:

1. Government and University management should endeavour to reduce the challenges involved in accessing TETFund for academic staff training to the barest minimum.
2. University management and government should maintain their policies of not allowing academic staff administrative experience influence their perception of the challenges involved in accessing TETFund for staff training.

3. Management of universities should endeavour to block the disparity between the perception of the challenges inherent in accessing TETFund for staff training between academic staff in the senior and junior cadres.

\section{References}

[1] Federal Republic of Nigeria (2014). National Policy on Education. Lagos: NERD.C

[2] Akomolafe, C. O. \& Belo, F. A. (2016). Influence of higher education on the development of the total person in Ekiti State. East African Journal of Educational Research and Policy, 11, 31-44.

[3] Ajayi, I.A. \& Ekundayo, H.T. (2006). Funding initiatives in University education in Nigeria. Being a paper presented at the National Conference of Nigerian Association. Educational Administration and Planning (NAEAP) Enugu State University of Science and Technology, Enugu.

[4] Agha, N.C \& Udu, G.O (2019). Quality and relevance of Tertiary Education Trust Fund intervention researches in tertiary institutions in South-East Nigeria (2010-2015). International Journal of Development and Management Review, 14 (1), 1-11.

[5] Udu, L. E. \& Nkwede, J. O. (2014). Tertiary Education Trust Fund interventions and sustainable development in Nigerian Universities: Evidence from Eboyi State University, Abakaliki: Journal of Sustainable Development, 7(4), 190-198.

[6] Bogoro, S.E (2015). Sustainability of higher education institutions in Nigeria: challenges and prospects. Retrieved from https://www.tetfund.gov.n $\mathrm{g}>$ news>

[7] Onyeizugbe, C. U., Obiageli, L. O. \& Igbodo, R.O. (2016). TETFND international programmes and academic staff development of selected Universities in South East Nigeria. Journal of Economics and Public Finance, 2(1) 181-193.

[8] Bogoro, S.E (2019) TETFund and the development of tertiary education in Nigeria: Strategies, performance and challenges. Being a paper presented by the Executive secretary, TETFUND, at the institute for security studies, Bwari, Federal Capital Territory, Abuja, Nigeria on 17th May 2019.

[9] TETFund Act (2011). About TETFund. Retrieved from http://www.tetfund.gov.ng 1 February 2014.

[10] Fasanmi, F. O. (1982). Supervision of industrial staff. Journal of the Faculty of Education, University of Nigeria, Nsukka. 17- 28. 
[11] Peretomode, V.F \& Peretomode, O. (2001). Human resources management. Lagos: Obaroh and Ogbinaka Publishers Ltd.

[12] Nakpodia, E. D (2011). Training and utilisation of staff and job performance in Post Primary Education Board in North Senatorial District of Delta State, Nigeria. Journal of Economics and International Finance. 3(5):279-288

[13] Onyeike, V. C \& Eseyin, E. O (2014). Tertiary Education Trust Fund and the Management of University Education in Nigeria. Global Journal of Educational Research, 13(1),63-72

[14] McLaughlin, T. (2007). Universities and Societies in Bridges et al. (eds.) Higher Education and National Development. London: Rout ledge

[15] Eno-Abasi, S. (2015). TETFund: Pendulum swings in favour of raised tax. Retrieved from File://:tetfund/TETFund pendulum swings in favour of raised tax. The Guardian, 10 September.

[16] Halidu, S.G (2015). The impact of training and development on workers' productivity in some selected Nigerian Universities. Retrieved from http://dx.doi.org/10.4172/2315-7844.100160 